\title{
Implementation of GCG Principles in Distribution of Credit in SOE/BUMD Bank
}

\section{Indra Gunawan Purba}

Lecturer of Faculty of Law, Al Azhar University Medan, Indonesia

Email: indrapurba07081978@gmail.com

\section{Abstract:}

The aims this study is to find out Implementation of GCG Principles in Distribution of Credit in SOE/BUMD Bank. This study use normative juridical research. The resul in this study shows that The board of directors and management of BUMN/BUMD banks absolutely must understand and apply the principles of GCG, especially in lending by applying the principles of GCG to prevent the occurrence of credit that has the potential to harm the company due to the lack of prudence and responsibility of officers to carry out loans. verification of customer data in the field. State-owned/BUMD Banks are required to be guided by the principles of GCG in implementing management so that the achievement of the goals and objectives, especially through the distribution of banking credit to the public and debtor customers can be obtained properly and maximally or at least not experiencing bad loans which have the potential to cause economic losses for the Bank BUMN/BUMD.

Keywords:

implementation; GCG Priciple; credit

\section{Introduction}

There are still many state-owned companies (BUMN/BUMD) that are not economically efficient. One of the factors that causes this to happen is the weak system of good corporate governance based on the principles of good corporate governance (GCG) in BUMN/BUMD. If this condition is left unchecked, the potential loss will occur and cause the possibility of a large burden to be borne by the state in an effort to maintain the management of SOEs.

The condition of banking in Indonesia has experienced problems leading to destruction. These problems come from macro and micro factors. Problems originating from macro factors stem from the economic crisis that has occurred since 1997/1998. This was marked by the exchange rate crisis which was marked by the decline in the value of the rupiah against the US Dollar by 109.6\% in December 1997 compared to the value of the rupiah in July 1997.

The macro problem is related to the micro problem, namely the emergence of a private debt crisis which resulted in a banking crisis. The fall in the value of the rupiah in $1997 / 1998$ was due to the poor quality of bank credit. This condition can be seen from the credit conditions after the crisis hit Indonesia, where the number of non-performing loans increased by 50\% in June 1998 from a total of Rp. 625.5 trillion distributed. This number increased when compared to 1996 , which was $10 \%$ of the total loans disbursed. 
Polit Journal: Scientific Journal of Politics

ISSN: 2775-5843 (Online), 2775-5835 (Print)

Vol. 1, No. 3, August 2021, Page: 118-128

Email: politjournal2@gmail.com six factors:

At least the collapse of the banking industry in Indonesia was caused by the following

1. Credit disbursement that is too expansive and spurred on by foreign inflows of funds which are vulnerable due to their short-term nature.

2. Providing credit without going through a sound credit analysis process.

3. Excessive concentration of credit to a business group or individual, whether related to the bank or not.

4. Moral hazard and the lack of firm exit policy mechanisms, as well as the protracted settlement of problem banks.

5. Excessive owner intervention in bank management, not even a few owners hold concurrent positions as bank administrators.

6. Weak aspects of banking supervision and regulation.

The breakdown of bank management is closely related to the provision of high-risk loans which in turn can have an impact on the security and health of the banking industry. The credit distribution process that occurs, for example, by the practice of mark-ups can destroy the banking industry itself. The mark-up of the requested loan funds can reach 10 times the real operating cash flow. Companies are trying to cover the shortfall in costs for company operations sourced from borrowed funds (credit). As a result, the company will suffer losses because it continuously borrows funds from abroad and even exceeds its own operating income. namely:

From the description of the background above, the researcher can draw a problem,

1. Implementation of the Principles of Good Corporate Governance (GCG) in providing credit to state-owned/BUMD banks.

2. Implementation of GCG principles in the legislation to ensure the fulfillment of prudential banking in the provision of credit to state-owned/BUMD banks.

\section{Research Methods}

As for this research, it uses normative juridical research, where normative juridical research includes research on legal principles. with regard to the implementation of GCG principles in the management of BUMN/BUMD Banks, especially with regard to credit distribution, as a normative research, researchers observe and explore legal norms regarding the provisions of positive Indonesian law that regulates related to the implementation of GCG principles in the management of BUMN/BUMD Banks, especially with regard to credit disbursement. The source of data used in this study is secondary data, which includes three legal materials, namely primary legal materials, secondary legal materials, and tertiary legal materials.

The nature of the research used in this study is prescriptive and descriptive. The nature of this research is not only to describe (describe) and describe the facts of credit assessment and credit analysis at state-owned/regional-owned banks, but also to analyze these facts normatively with several approaches. Descriptive describes the facts of lending practice, while prescriptive analyzes, justifies, and assesses the reasons regarding the implementation of GCG principles in the management of BUMN/BUMD Banks, especially with regard to credit disbursement. 


\section{Discussion}

\subsection{Implementation of the Principles of Good Corporate Governance (GCG) in Providing}

Credit to State-owned/BUMD Banks

The problem of lending in Indonesia can also be observed from the amount of credit disbursed by banks to their own business groups, as has been done by the National Dagang Bank (BDNI), Danamon Bank, and Modern Bank. Such action violates the Maximum Lending Limit (LLL), which stipulates that banks are prohibited from extending credit of more than $20 \%$ of their capital to a single company or group of companies. If the debtor customer is a party related to the bank, the maximum credit disbursed should be $10 \%$ of the bank's capital.

Violations of the LLL provisions occurred in October 1995, for example, in Bank Anrico, which provided loans to its subsidiary in the amount of $1.925 \%$ of its capital. Bank Jakarta disbursed loans to related companies more than twice its capital. The same case occurred in several state-owned banks which attracted the attention of the Supreme Audit Agency (BPK) to conduct an examination, and found irregularities in credit distribution in several state-owned banks for violations of the LLL.

The problem can be observed from the provision of credit to its own business group, which is often not accompanied by the provision of sufficient collateral. In the United States, lending that is not secured by adequate provision is categorized as fraud. Trial in the case of FDIC vs. WR. Grace \& Co, 877 Fed 2d 614 (7th cir 1989) argues, that the debtor is declared fraudulent if he does not notify the creditor that the guarantee provided is not sufficient.

Problems in providing credit are the cause of bank failures in carrying out their functions and from these problems, among others, the causes of failure can be described in terms of errors (intentional and negligence) committing fraud or embezzlement practices, KKN, and so on. Therefore, problems in providing credit need to be anticipated with adequate credit implementation regulations based on GCG principles and commitments for their implementation in the field.

The board of directors and management of BUMN/BUMD banks absolutely must understand and apply the principles of GCG. This understanding is useful for further deepening the issue of how to efficiently manage BUMN/BUMD banks, especially in channeling credit to debtor customers. It is intended that the application of GCG principles can prevent the occurrence of credit disbursement that has the potential to harm the company due to the lack of prudence and responsibility of officers to verify customer data in the field.

One of the causes of the vulnerability of companies to be affected by economic turmoil is due to the weak application of GCG principles in company management. Public and investor perceptions of the implementation of GCG in Indonesian companies are also low. These weaknesses can be seen from the lack of financial performance reporting, the lack of supervision over management activities by the commissioners and auditors, as well as the lack of incentives to encourage the creation of company efficiency through fair competition mechanisms.

There are four general principles of GCG that must be applied, namely fairness, transparency, accountability and responsibility. In connection with efforts to create good corporate governance, the management of BUMN/BUMD Banks must strive for the implementation of GCG principles considering the importance of the role of banks as the heart 
and driving force of the economy in a country to support business activities in the financial sector.

Banks as trust holders in a fiduciary duty relationship must act as trust holders from those who place their funds in the bank. The function of the bank as a financial intermediary between the party placing funds in the bank and the party requiring funds from the bank is obtained through credit. So with this main function, banks must mobilize public funds appropriately and quickly channel them to effective and efficient use or investment.

BUMN/BUMD Banks in carrying out their main functions to mobilize public funds and channel them back to the community who need funds in the form of credit for use or investment must be carried out efficiently, fairly, responsibly and responsibly. Thus, with the application of GCG principles, bank officers in the credit sector must carry out their responsibilities to verify the required data in the field, in accordance with the provisions of the applicable SOP.

The implementation of GCG principles needs to be considered by the board of directors and management to achieve the company's goals as a business seeking economic benefits. The principle of prudence in lending is an effort that cannot be separated from the mandate of GCG principles. Officers who are not careful in verifying debtor customer data have the potential to harm the company and if this is done by BUMN/BUMD Bank officers, it can be considered corruption in connection with SOP violations. The obligation to carry out the responsibility for verifying credit data/documents, both in the field and administratively, is a mandate from the GCG principles, namely the principles of accountability and responsibility.

Accountability is a concept of an organization's responsibility to explain and show the achievement of its performance in accounting (administrative) or financial reports to stakeholders. All actions and policies must be accountable to stakeholders. In the financial management system, accountability requires that financial management be accounted for in a transparent manner to interested stakeholders for it in accordance with accounting principles and applicable laws and regulations.

The principle of accountability is the principle that contains the authorities that must be owned by the board of directors or management and their obligations to shareholders and stakeholders administratively. In general, the directors are responsible for the company's performance reports. In particular, the lower management and so on until the bank employees are responsible for reports and documents according to their respective fields which must be accountable to the board of directors and/or to stakeholders. Company managers should avoid unfair transaction costs and have the potential to harm the company.

The principle of responsibility (responsibility) is a principle in company management thatdemands that the company's management or leadership (board of directors) and managers and all parties managing the company carry out their activities responsibly in carrying out their legal obligations. If a legal problem occurs, the board of directors and management in credit management must be responsible before the law for what is done during the implementation of credit distribution that is detrimental to the company or the occurrence of non-performing loans caused by management error.

The principle of transparency is a principle of good corporate governance that must provide timely and accurate information. Information disclosed includes, among others, financial 
condition, financial performance, ownership and management of the company. Audits conducted on information are carried out independently and with the correct mechanism in accordance with the company's business practices. Disclosure is carried out so that shareholders and other interested parties know the condition of the company in order to take the necessary steps.

The implementation of the principle of transparency (openness) can describe an assessment to ensure that the management of the company is carried out properly and fulfills legal and statutory obligations. The principle of transparency emphasizes that the company's management framework must ensure that accurate and appropriate disclosure of information is carried out in relation to material concerning the company, including the financial situation, performance, ownership and leadership of a company.

The principle of fairness is a principle that requires all stakeholders to have the opportunity to get fair treatment in the management of the company by the board of directors. The application of this principle within the company will prohibit disgraceful practices carried out by insiders that harm other parties.

Company management must pay attention to the interests of shareholders and stakeholders in a fair and equitable manner. The Board of Directors must act if they find transactions that contain conflicts of interest. If nepotism is found in lending to someone, then it must be re-verified for completeness of credit documents.

The general principles of GCG for managing corporate governance can be developed more specifically, covering many aspects, including all the company's relationships with capital, products, services or human resource providers, customers, and the wider community. Includes all legal rules aimed at enabling companies to be responsible, accountable, and transparent in front of shareholders, can also refer to audit practices, bookkeeping principles, and also refer to the activities of shareholders.

Corporate governance can also be seen from the role and practice of the board of directors in a relationship of trust as an agent of the shareholders who are trusted to ensure a company is managed properly and carefully for the benefit of the company. In addition to covering the rule of law, it also includes policies that enable companies to be able to attract investors and enter capital, perform efficiently, generate profits and meet stakeholder expectations and obey the law.

Good corporate governance at the philosophical level is also in line with the demands of business ethics, morals, and ethics. Business ethics is concerned with the specific arrangements of morals, right and wrong, focusing on the moral standards applied in business policies, institutions and conduct. An activity of the company's organs must be based on the moral standards of how it is applied to the company's systems and organizations to produce and distribute goods and services.

The basic obligation of management is not only to maximize the success of profit, but how to ensure its survival by balancing the competing demands of various stakeholder interests. Therefore, it is necessary to have ethical guidelines or code of conduct, which cannot be released for companies that lead to good corporate governance based on ethical and moral demands. 
BUMN/BUMD as a limited liability company is subject to the RI Law No. 40 of 2007 concerning Limited Liability Companies. In Article 4 of RI Law No. 40 of 2007 and its explanation, it is stated that the enactment of this law, the Company's Articles of Association, and other statutory provisions, does not reduce the obligation of each company to comply with the principle of good faith, the principle of propriety, the principle of propriety, and the principles of good corporate governance in managing the company.

\subsection{Implementation of GCG Principles in the Legislation to Ensure the Fulfillment of} Prudential Banking in the Provision of Credit to State-owned/BUMD Banks

GCG principles are built with reference to the principles of transparency, accountability, responsibility, fairness, and independence (independence). These principles were adopted in the RI Law No. 40 of 2007 and RI Law No. 19 of 2003, various other related regulations, the Articles of Association and subsequently derived by the company in various internal products, such as the code of conduct, code of GCG, and various manual operating procedures, or SOPs that serve as guidelines in managing the company.

The government through the RI Law No. 19 of 2003 has adopted the principles of GCG to overcome the weak management of SOEs. This provision is expressly stated in Article 36 paragraph (1) of Law No. 19 of 2003 which states that a public company (perum) in carrying out its business must be based on the principles of sound corporate governance.

Normative provisions related to GCG principles are also regulated in Article 5 paragraph (3) and Article 6 paragraph (3) of Law No.19 of 2003 which requires directors, commissioners and supervisory boards in carrying out their duties to carry out the principles of professionalism. , efficiency, transparency, independence, accountability, responsibility and fairness.

Furthermore, the follow-up to the regulation of GCG principles in the Law of the Republic of Indonesia No. 19 of 2003 can be found in Article 16 paragraph (3) and Article 19 paragraph (4) of Law No. 19 of 2003 which states that every member of the Board of Directors who has passed the due diligence test must signed a management contract before being appointed as a member of the board of directors. This provision is intended so that the Board of Directors is committed, professional, and transparent in managing the company.

The provisions of Article 25, Article 33 and Article 53 of Law No.19 of 2003 RI prohibits directors, commissioners, and supervisory boards from holding concurrent positions. Article 21-23, Article 49-51, Article 32, Article 54, and Article 61 further regulate the responsibilities of the directors, commissioners and supervisory boards. This is intended to maintain the independence and independence of the directors, commissioners and supervisory boards.

Provisions that guarantee accountability, RI Law No.19 of 2003 requires the establishment of an Audit Committee and Other Committees (Article 70) and requires an external auditor to examine financial statements (Article 71). The accountability principle emphasizes the financial and administrative responsibility of state-owned banks related to their performance achievements in accounting (administrative) or financial reports to stakeholders.

Provisions that guarantee the fulfillment of corporate social responsibility (CSR), Law of the Republic of Indonesia No. 19 of 2003 allows the formation of labor unions as a forum for channeling aspirations from employees so that their rights can be fulfilled (Article 87 paragraph 2), providing certainty to employees. BUMN distributes part of its net profit for the 
development of small businesses / cooperatives and community development around the company (Article 88 paragraph 1), and regulates donations for charity and social purposes (Article 90).

RI Law No. 19 of 2003 has normatively adopted the general principles of GCG plus one additional principle, namely efficiency. However, it should be noted that the normative provisions are only general and abstract in nature and require further interpretation and implementation by management in order to function properly in the field. It is also important to guard against abuse of state-owned banks and to measure the performance of the board of directors of state-owned banks.

Good corporate governance (GCG) is confirmed in Article 1 point 1 of the Ministerial Regulation (Permen) of BUMN Number: Per-01/MBU/2011 concerning the Implementation of Good Corporate Governance in BUMN, as amended through the Minister of BUMN Number: Per-09/MBU/2012 concerning Amendments to the Minister of State-Owned Enterprises Regulation Number: PER-01/MBU/2011 concerning the Implementation of Good Corporate Governance in BUMN, namely the principles that underlie a company management process and mechanism based on laws and regulations and business ethics.

Based on the Decree of the Minister of SOEs Number: Kep-117/M-MBU/2002 concerning the Implementation of GCG Practices in SOEs, good corporate governance (GCG) is defined as a process of the structure used by SOEs to improve business success and corporate accountability in order to realize shareholder value. Shares in the long term by taking into account the interests of stakeholders, based on laws and regulations and ethical values.

Article 2 paragraph (1) of the Minister of SOEs Number: Per-01/MBU/2011 confirms that the implementation of GCG principles is an obligation for SOEs. All state-owned companies are required to apply GCG principles consistently and sustainably while still taking into account the provisions of applicable laws and norms or business ethics and the articles of association of SOEs.

The general consideration of the importance of the obligation to apply GCG principles to SOEs in the SOE Ministerial Regulation Number: Per-01/MBU/2011 is related to legal reforms in the field of limited liability companies and BUMN, as well as paying attention to the development of an increasingly dynamic and competitive business world.

Article 3 of the Minister of SOEs Number: Per-01/MBU/2011, states that there are five principles of GCG in the management of BUMN companies, namely the principles of transparency (transparency), accountability (accountability), independence (independency), responsibility (responsibility), and fairness.

The principle of transparency emphasizes openness in carrying out the decision-making process and openness in disclosing material and relevant information regarding BUMN/BUMD Banks. Accountability, regarding the clarity of functions, implementation and accountability of organs so that the management of BUMN/BUMD Banks is carried out effectively. Accountability confirms conformity in the management of BUMN/BUMD Banks to the laws and regulations and sound corporate principles.

Independence, namely a condition in which BUMN/BUMD Banks are managed professionally without conflict of interest and influence/pressure from any party that is not in 
accordance with the laws and regulations and sound corporate principles. Fairness is related to the fulfillment of justice and equality in fulfilling the rights of stakeholders that arise based on agreements and laws and regulations.

The purpose of applying these GCG principles to SOEs according to Article 4 of the SOE Ministerial Regulation Number: Per-01/MBU/2011 is intended to:

1. Optimizing the value of SOEs so that they have strong competitiveness, both nationally and internationally, so that they are able to maintain their existence and live sustainably to achieve the aims and objectives of SOEs;

2. Encouraging the management of BUMN in a professional, efficient, and effective manner, as well as empowering the functions and increasing the independence of the Persero organs / Perum organs;

3. Encouraging Persero organs / Perum organs in making decisions and carrying out actions based on high moral values and compliance with laws and regulations, as well as awareness of the existence of BUMN social responsibility towards stakeholders and environmental sustainability around BUMN;

4. Increase the contribution of SOEs in the national economy; and

5. Improving a conducive climate for the development of national investment.

The policy of the board of directors in the context of implementing GCG principles, according to Article 2 paragraph (1) SOE Ministerial Regulation Number: Per-01/MBU/2011, is required to compile a GCG manual including the manual board, risk management manual, internal control system, internal control system, reporting mechanism for alleged irregularities in the relevant BUMN, information technology governance, and code of conduct.

Government Regulation (PP) RI No. 54 of 2017 concerning BUMD also adopts the principles of GCG. In Article 1 point 9 of the PP it is determined that good corporate governance is a management system that directs and controls the company in order to produce sustainable economic benefits and a balanced relationship between stakeholders. Good corporate governance is established by the BUMD directors.

The management of BUMD is carried out in accordance with the principles of good corporate governance as stipulated in Article 92 of PP RI No. 54 of 2017, namely: transparency, accountability, responsibility, independence, and fairness. The application of these principles aims to:

1. Achieving BUMD objectives;

2. Optimizing the value of BUMD so that companies have strong competitiveness, both nationally and internationally;

3. Encouraging the management of BUMD in a professional, efficient, and effective manner, as well as empowering functions and increasing the independence of BUMD organs;

4. Encouraging BUMD organs in making decisions and carrying out actions based on high moral values and compliance with laws and regulations, as well as awareness of social responsibility towards stakeholders as well as environmental sustainability around BUMD;

5. Increase the contribution of BUMD in the national economy; and

6. Improving a conducive business climate for the development of national investment. 
The application of GCG principles in the management of BUMN/BUMD must be carried out comprehensively and thoroughly on all aspects and scope of its application not only related to legal aspects but also ethical and moral aspects. Therefore, documents for implementing GCG principles are inadequate if they only cover basic legal documents such as the company's articles of association, but also include by-laws set by the company's internals.

Documents in the implementation of GCG that must be held by the SOE/BUMD board of directors to ensure the implementation of GCG principles include: the company's articles of association, board manuals of directors and commissioners, risk management guidelines, internal control system manuals, internal control system manuals, whistleblower systems, information technology governance, code of conduct, guidelines for procurement of goods and services, key performance indicators, and integrity pacts.

The implementation of GCG principles is admittedly difficult to implement in the practice of corporate management, especially in relation to the distribution of bank loans to state-owned/BUMD banks due to the attraction between various different interests. GCG principles in managing the company if implemented properly can improve performance and create added value for the company. GCG principles are needed solely to achieve the company's goals and objectives as a business seeking economic benefits.

The role of the board of directors in managing BUMN/BUMD Banks is very decisive as the spearhead as well as a determining factor for the success of the company. Ideally, BUMN/BUMD banks should not be merely a tool used to fulfill the personal goals of directors, commissioners, as well as management and employees, but must function properly as one of the pillars of national economic development that has added value for the community, taxes, providers employment opportunities, and export-import.

Based on the discussion, it is important for any company, especially BUMN/BUMD Banks, to be guided by the principles of GCG in carrying out management so that the achievement of goals and objectives, especially through the distribution of banking credit to the public and debtor customers, can be obtained properly and maximally or at least not. Experiencing bad credit which has the potential to cause economic losses for BUMN/BUMD Banks.

\section{Conclusion}

1. The board of directors and management of BUMN/BUMD banks absolutely must understand and apply the principles of GCG, especially in lending by applying the principles of GCG to prevent the occurrence of credit that has the potential to harm the company due to the lack of prudence and responsibility of officers to carry out loans. verification of customer data in the field

2. State-owned/BUMD Banks are required to be guided by the principles of GCG in implementing management so that the achievement of the goals and objectives, especially through the distribution of banking credit to the public and debtor customers can be obtained properly and maximally or at least not experiencing bad loans which have the potential to cause economic losses for the Bank BUMN/BUMD. 


\section{References}

Article 36 paragraph (1) of the RI Law No.19 of 2003 concerning BUMN, stipulates: "The purpose and objective of Perum is to carry out a business aimed at the public benefit in the form of providing quality goods and/or services at affordable prices by the community based on the principles of company management healthy one."

Bismar Nasution, "Towards an Effective and Efficient SOE Management System", Paper, Presented at a Seminar on the Development and Management System of State-Owned Enterprises, Organized by the Office of the Ministry of State-Owned Enterprises, Medan, December 14, 2005, p. 1.

Bismar Nasution, "Implementation of Good Corporate Governance in Prevention of Credit Misuse", Paper, Presented at Credit Law Seminar, PT. Bank Rakyat Indonesia, Medan, March 12-13, 2002, p. 2.

Bismar Nasution, "Legal Aspects in the Transparency of the Management of BUMN/BUMD Companies as an Effort to Eradicating KKN", Paper, Presented at the Workshop on the Role of the Community (Stakeholders) Through the Supervisory Agency for Company Management in Supporting the Implementation of Good Corporate Governance in North Sumatra, April 30, 2003, p. 5.

Bismar Nasution, "Good Corporate Governance in Legal Perspective", Paper, Delivered at the One Day Seminar on Good Corporate Governance (GCG) PT. State Electricity Company (Persero) and Subsidiaries, Organized by PT. State Electricity Company, Batam, August 29 2019, p. 6.

Bismar Nasution, "Good Corporate Governance in Legal Perspective", Paper, Delivered at the One Day Seminar on Good Corporate Governance (GCG) PT. State Electricity Company (Persero) and Subsidiaries, Organized by PT. State Electricity Company, Batam, August 29 2019, p. 5.

Bismar Nasution, "Legal Aspects in... Op. cit., p. 4.

Bismar Nasution, "Good Corporate Governance in... Op. cit., p. 4.

Bismar Nasution, "Legal Aspects in... Op. cit., p. 2.

Bismar Nasution, "Good Corporate Governance in... Op. cit., p. 1.

Bismar Nasution, "Good Corporate Governance in... Op. cit., p. 7.

Bismar Nasution, "Good Corporate Governance in... Op. cit., p. 2.

Bismar Nasution, "Towards a BUMN Management System... Op. cit., p. 3.

Bismar Nasution, "Good Corporate Governance in... Op. cit., p. 9.

Bismar Nasution, "Implementation of Good Corporate Governance... Loc. cit.

Bismar Nasution, "Implementation of Good Corporate Governance.... Op. cit., p. 1.

Bismar Nasution, "The Responsibilities of the Board of Directors and... Op. Cit., p. 4.

Bismar Nasution, "Implementation of Good Corporate Governance... Op. cit., p. 2.

Mukti Fajar \& Yulianto Achmad, Dualism of Normative and Empirical Legal Research, (Yogyakarta: Pustaka Pelajar, 2012), p. 156-159.

M. Marwan \& Jimmy P., Op. cit., p. 9. Read also: Henry Campbell Black, Op. cit., p. 19.

Peter Mahmud Marzuki, Legal Research, (Jakarta: Kencana Prenada Media Group, 2005), p. 103. Also read: Bambang Sunggono, Legal Research Methodology, (Jakarta: RajaGrafindo Persada, 1998), p. 101. Comparative legal research is to examine the legal comparison between one law and another, for example between colonial product laws and national product laws, as well as examining the comparison between 2 (two) different legal systems, between European legal systems continental (civil law system) and the Anglo Saxon legal system (common law system) adopted by one country to another, between the legal system of the unitary state and the federal state. It is further stated that the comparative law methodology may be applied by using elements of the legal system as a 
starting point for comparison, where the legal system itself includes three elements: (1) the legal structure which includes legal institutions, (2) the legal substance concerning the set of rules or behavior of the apparatus; and (3) legal culture regarding the set of values adopted. These three elements can be compared with each other or cumulatively.

Peter Mahmud Marzuki, Op. cit., p. 96.

Siti Sundari Arie, Op. Cit., p. 2.

Widigdo Sukarman, "Efforts to Restructure the Banking and Real Sector," Business \& Political Economy Quaterly Review of the Indonesia Economy, Vol.3, No.1 (January 1999), p. 21. Zulkarnain Sitompul, Loc. cit. 